\title{
On the taxonomy of the Neotropical spider genera Dossenus and Dyrines (Araneae: Lycosoidea: Trechaleidae) from Brazil
}

\author{
Estevam L. C. da Silva \& Arno A. Lise \\ Laboratório de Aracnologia, Museu de Ciências e Tecnologia, Pontifícia Universidade Católica do Rio Grande do Sul. Avenida \\ Ipiranga 6681, Prédio 40, Sala 125, 90619-900 Porto Alegre, Rio Grande do Sul, Brazil. E-mail: estevamsilva@gmail.com
}

\begin{abstract}
The male of Dossenus guapore Silva, Lise \& Carico, 2007 is described and illustrated for the first time, based on material from Bonito, Mato Grosso do Sul, Brazil. The spider genus Dossenus Simon, 1898 is distributed from Panama to southern Brazil and can be distinguished by the other known genera of Trechaleidae by the median dark brown band on the carapace that extends to the abdomen and by the spoon-like shape of the median apophysis of the male palpus. A new species of Dyrines Simon, 1903, D. brescoviti sp. nov., is described and illustrated based on material collected in Sergipe and Paraná, Brazil. The representatives of this spider genus are relatively small and can be distinguished from the other genera by the longitudinal dark brown bands on the legs. New records of Dyrines striatipes (Simon, 1898) are presented.

KEY WORDS. Morphology; Neotropical region; new species; taxonomy.
\end{abstract}

Dossenus Simon, 1903 was recently revised by SiLva et al. (2007) and includes two species: D. marginatus Simon, 1898 (type-species) (Trinidad-Tobago, Colombia, Peru, Brazil) and $D$. guapore Silva, Lise \& Carico, 2007 (Panama, Brazil) (Platnick 2010). The representatives of this genus are characterized by the median dark brown band on the carapace that extends to the abdomen, the male palpus resembles the ones of Enna O.P. Cambridge, 1897 by the spoon-like shape of the median apophysis of the male palpus, the female epigynum presents a slightly projected scape (SILVA et al. 2007).

Dyrines Simon, 1903 was recently revised by CARICO \& Silva (2008) and now includes only three species: Dyrines striatipes (Simon, 1898) (type species, Panama to Venezuela), D. ducke Carico \& Silva, 2008 (Amazonas, Brazil) and D. huanuco Carico \& Silva, 2008 (Huanuco, Peru) (Platnick 2010). The representatives of this spider genus are relatively small if compared to other larger species, e.g., Trechalea Thorell, 1869. The main character that can be used to separate the specimens of this genus from other species, are the longitudinal dark bands on the legs (Carico \& Silva 2008).

The distribution of this genus was restricted to the Amazon area, especially in Brazil. The present new record from northeastern Brazil (Bahia) increases the occurrence of the genus.

In this work we describe and illustrate the male of D. guapore from Mato Grosso do Sul, Brazil and a new species of Dyrines from Sergipe, Brazil and new records of Dyrines striatipes are given.

\section{MATERIAL AND METHODS}

The material examined is deposited in Instituto Butantan, São Paulo, Brazil (IBSP, A.D. Brescovit) and Museu de Ciências e Tecnologia of Pontifícia Universidade Católica do Rio Grande do Sul (MCTP, A.A. Lise). The nomenclature of the male palpus structures follows CARICO (1993), Silva et al. (2007) and CARICO \& SILVA (2008). All the measurements are in millimeters. The abbreviations related to eye measurements, including diameter, interdistances and median ocular quadrangle are those routinely used in spider descriptions.

\section{TAXONOMY}

\section{Dossenus guapore Silva, Lise \& Carico, 2007} Figs 1-2

Dossenus guapore Silva et al. 2007: 147, figs 1, 19, 20, 31, 32, female holotype from Usina Hidrelétrica de Guaporé, Vale do São Domingos, Mato Grosso, Brazil, X.1999, Equipe Resgate leg. (IBSP 41643) (examined); Platnick, 2010.

Diagnosis. The male of $D$. guapore resembles the ones of D. marginatus Simon, 1898 by the general shape of the median apophysis and retrolateral tibial apophysis (SiLVA et al. 2007, figs 5 and 6), but can be distinguished by the wider base of the ventral division of the median apophysis (VD) (Fig. 1) and by the acute apex of the retrolateral tibial apophysis (Fig. 2).

Description. Male (IBSP 52861). Total length 5.89. Carapace 2.57 long, 2.49 wide, light brown with median brownish band, rounded by a band of whitish setae. Clypeus brownish, 0.24 high. Anterior eye row straight, 0.62 wide; posterior 1.39 wide, recurved. Eye diameters, interdistances, and median ocular quadrangle: AME 0.11, ALE 0.09, PME 0.21, PLE 0.18; AMEAME 0.09, AME-ALE 0.06, PME-PME 0.27, PME-PLE 0.26, OQA 0.34 , OQP 0.58, OQH 0.52. Chelicerae dark brown, bristly, light 

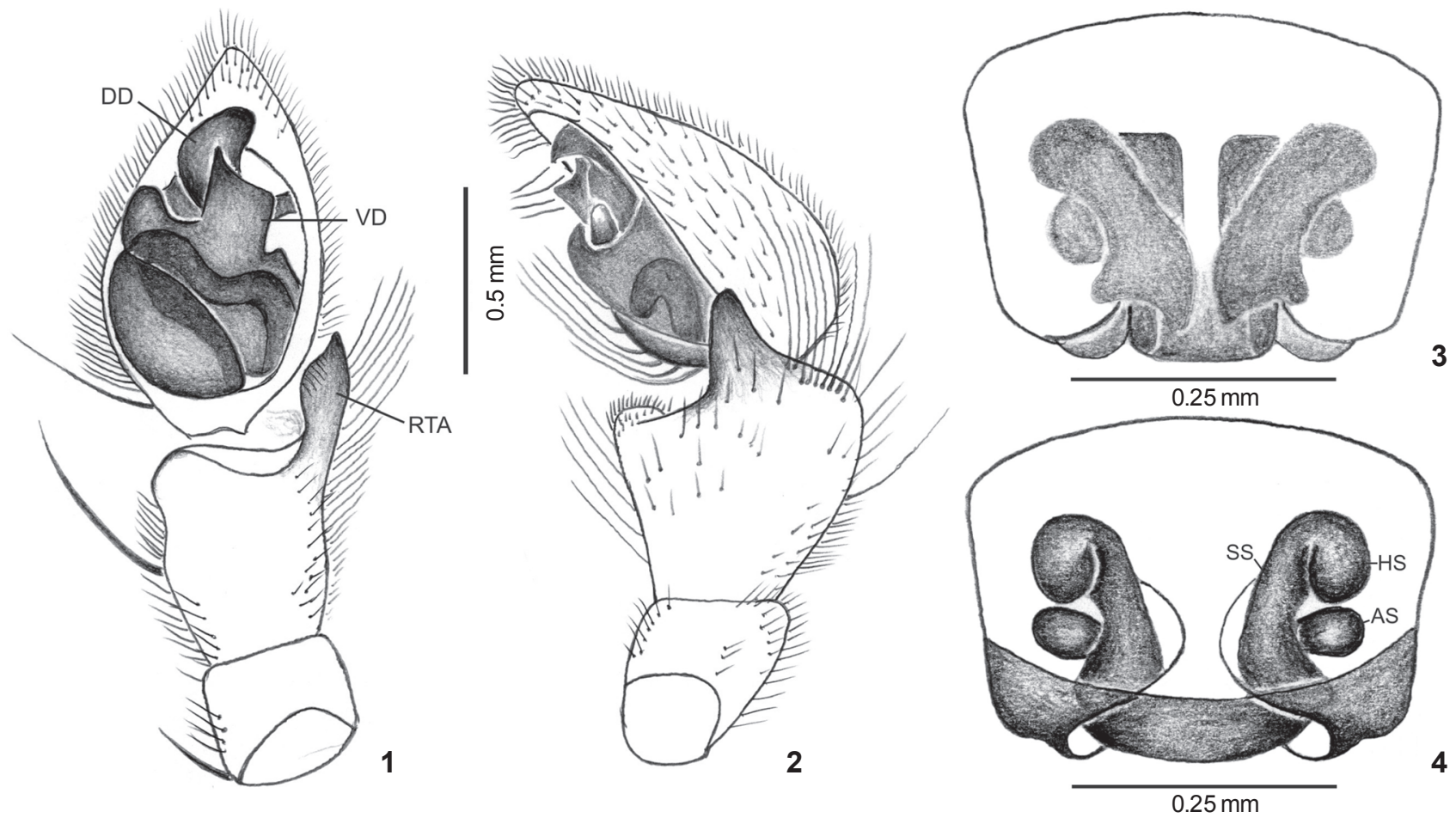

Figures 1-4. Dossenus guapore, male palpus: (1) ventral view; (2) retrolateral view. (3-4) Dyrines brescoviti sp. nov., female epigynum: (3) ventral view; (4) dorsal view. (AS) Accessory spermathecae, (DD) dorsal division of median apophysis, (HS) head of spermathecae, (MS) medium septum, (RTA) Retrolateral tibial apophysis, (SS) stalk of spermathecae, (VD) ventral division of median apophysis.

brown near fang; promargin and retromargin of fang furrow with three teeth equidistant and equal in size. Sternum yellowish, scattered setae; 1.33 long, 1.30 wide. Labium dark brown, lighter posteriorly, 0.31 long, 0.44 wide. Legs dark brown with light brown spots, relative length: I-IV-II-III, I - femur 3.07 /tibia-patella 4.15 /metatarsus 3.65 /tarsus 1.32 /total 12.19 ; II - 3.15/4.23/3.32/1.24/11.94; III - 1.90/2.49/1.90/0.99/7.28; IV - 3.16/3.73/3.81/1.33/12.03. Ventral pairs of macrosetae on tibiae: I-5; II-5; III-3; IV-3. Abdomen, 3.40 long, dark brown, with a median light brown band rounded by a line of white setae, strong setae anteriorlly. Venter light brown, with two thin brownish bands; scattered setae. Palpus with rounded dorsal division of the median apophysis and ventral division wider at the base (Fig. 1). Retrolateral tibial apophysis with an acute apex (Fig. 2).

Material examined. Brazil: Mato Grosso do Sul: Bonito (Abismo Anhumas, $21^{\circ} 10^{\prime} \mathrm{S}, 56^{\circ} 35^{\prime} \mathrm{W}$ ), male, 14-23.X.2002, Equipe Biota leg. (IBSP 52861).

Distribution. Panama, Colombia, Brazil (Amazonas, Mato Grosso, Mato Grosso do Sul, São Paulo).

Remarks. The male can be considered co-specific with the female holotype of $D$. guapore because the type locality is in the same range of occurrence for the species. Since after the revision, most of the known species were synonymyzed, and only one new species was described at that time (D. guapore). Thus D. marginatus even present a wide distribution from Central America (Panama) to southern Brazil the differences between the two males are very conspicuous.

\section{Dyrines brescoviti sp. nov.}

Figs 3-4

Diagnosis. The female of $D$. brescoviti sp. nov. resembles the ones of $D$. striatipes (Carico \& SiLva 2008, figs 6 and 7), by the shape of the middle field of the epigynum (Fig. 1), but can be distinguished by the general shape of the spermathecae (Fig. 4), disposition of the accessory spermathecae and by the separated medium septum (Fig. 3).

Description. Female, holotype. Total length 3.81. Carapace 2.10 long, 1.95 wide, light brown, darker laterally, small thin whitish band. Clypeus brownish, 0.10 high. Anterior eye row slightly straight, 0.60 wide; posterior 0.98 wide. Eye diameters, interdistances, and median ocular quadrangle: AME 0.16 , ALE 0.06, PME 0.15, PLE 0.14; AME-AME 0.08, AME-ALE 0.08, PME-PME 0.12, PME-PLE 0.20, OQA 0.32, OQP 0.44, OQH 0.38. Chelicerae light brown, with two brownish longitudinal bands, bristly, without lateral carina; promargin and retromargin of fang furrow with three teeth equidistant and equal in size. Ster- 
num yellowish, scattered setae; 1.08 long, 0.99 wide. Labium light brown, darker anteriorlly, 0.31 long, 0.34 wide. Legs brownish with light brown longitudinal bands extending from femora to tarsi, relative length: I-IV-II-III, I - femur 2.69/tibiapatella $3.78 /$ metatarsus $3.16 /$ tarsus $1.11 /$ total $10.74 ;$ II -2.32 / 2.88/2.32/0.78/8.30; III - 1.39/1.73/1.55/0.71/5.38; IV - 2.48/ $2.63 / 2.91 / 0.83 / 8.85$. Ventral pairs of macrosetae on tibiae: I-5; II-5; III-4; IV-3. Abdomen, 1.70 long, light brown, bristly, dorsum with four conspicuous sigilla, darker anteriorlly. Venter yellowish, scattered setae. Female epigynum with prominent scape (Fig. 3). Head of spermathecae globular and directed ventrally (Fig. 4) and accessory spermathecae circular at the base of spermathecae stalk (Fig. 4).

Male. Unknown.

Type. Female holotype from Estação Ecológica da Serra de Itabaina, Itabaina, Sergipe, Brazil $\left(10^{\circ} 40^{\prime} \mathrm{S}, 37^{\circ} 25^{\prime} \mathrm{W}\right), 14-$ 20.IX.1999, A.D. Brescovit leg., deposited in Instituto Butantan (IBSP 57729). One female paratype from Morretes, Paraná, Brazil, 09-19.I.1995, A. Braul leg., deposited in МСТP 12326.

Distribution. Brazil (Sergipe, Paraná).

Etymology. The specific name is a patronym in honor of the collector of the type-species, A.D. Brescovit.

\section{Dyrines striatipes (Simon, 1898)}

Drances striatipes Simon, 1898: 18.

Dyrines striatipes: Simon, 1903: 1045; Petrunkevitch, 1925: 543; Roewer, 1954: 136; Bonnet, 1956: 1615; Sierwald, 1990; Carico \& Silva, 2008; Platnick, 2009.

Dyrines lineatipes Petrunkevitch, 1925: 166, figs 86, 87; Carico \& Silva, 2008: 112; Platnick, 2009. Syn. nov.

Distribution. Panama, Venezuela, Guyana, Brazil.

Addtional record. BraziL, Bahia: Itabuna (Fazenda São Francisco), 1 male, 26.III.1970, CEPLAC leg. (IBSP 15811).

\section{ACKNOWLEDGMENTS}

We wish to thank Antonio D. Brescovit (IBSP) for the loan of the material. This study was supported by Conselho
Nacional de Desenvolvimento Científico e Tecnológico (CNPq Proc. 140282/2008-4 for ELCS).

\section{LITERATURE CITED}

BonNET, P. 1956. Bibliographia Araneorum. Analyse méthodique de toute la litterature aranéologique jusqu'en 1939. Tome II, 3e partie: C-F. Toulouse, Les Artisans de l'Imprimerie Douuladoure, p. 919-1925.

Carico, J.E. 1993. Revision of the genus Trechalea Thorell (Araneae, Trechaleidae) with a review of the taxonomy of the Trechaleidae and Pisauridae of the Western Hemisphere. Journal of Arachnology 21 (3): 226-257.

CARICO, J.E. \& E.L.C. SiLVA. 2008. Revision of the Neotropical spider genus Dyrines (Araneae, Lycosoidea, Trechaleidae). Journal of Arachnology 36 (1): 111-117.

Petrunkevitch, A. 1925. Arachnida from Panama. Transactions of the Connecticut Academy of Arts and Sciences 27: 51248.

Platnick, N.I. 2010. The World Spider Catalog version 10.5 . New York, American Museum of Natural History, available on line at: http://research.amnh.org/entomology/spiders/ catalog/html [Access: 31.III.2010].

Roewer, C.F. 1954. Katalog der Araneen von 1758 bis 1940, bsw. 1954. Bruxelles, Institut Royal des Sciences Naturelles de Belgique, vol. 2a, 923p.

Silva, E.L.C.; A.A. Lise \& J.E. Carico. 2007. Revision of the Neotropical spider genus Dossenus (Araneae, Lycosoidea, Trechaleidae). Insect Systematics \& Evolution 38: 139-148.

SiERWALD, P. 1990. Morphology and homologous features in the male palpal organs in Pisauridae and other spider families with notes on the taxonomy of Pisauridae (Arachnida: Araneae). Nemouria. Occasional Papers of the Delaware Museum of Natural History 35: 1-59.

SIMON, E. 1898. Descriptions d'arachnides nouveaux des familles des Agelenidae, Pisauridae, Lycosidae et Oxyopidae. Annales de la Société Entomologique de Belgique 42: 1-34.

Simon, E. 1903. Histoire naturelle des araignées, deuxiéme édition. Paris, Librairie encyclope'dique de Roret, Tome 2, Fascicule 4, p. 669-1080.

Submitted: 21.VII.2009; Accepted: 31.III.2010.

Editorial responsibility: Antonio Domingos Brescovit 